\title{
No Inversion of Epiglottis During Swallowing
}

National Cancer Institute

\section{Source}

National Cancer Institute. No Inversion of Epiglottis During Swallowing. NCI Thesaurus.

Code C127243.

A finding of no inversion of epiglottis during swallowing. 